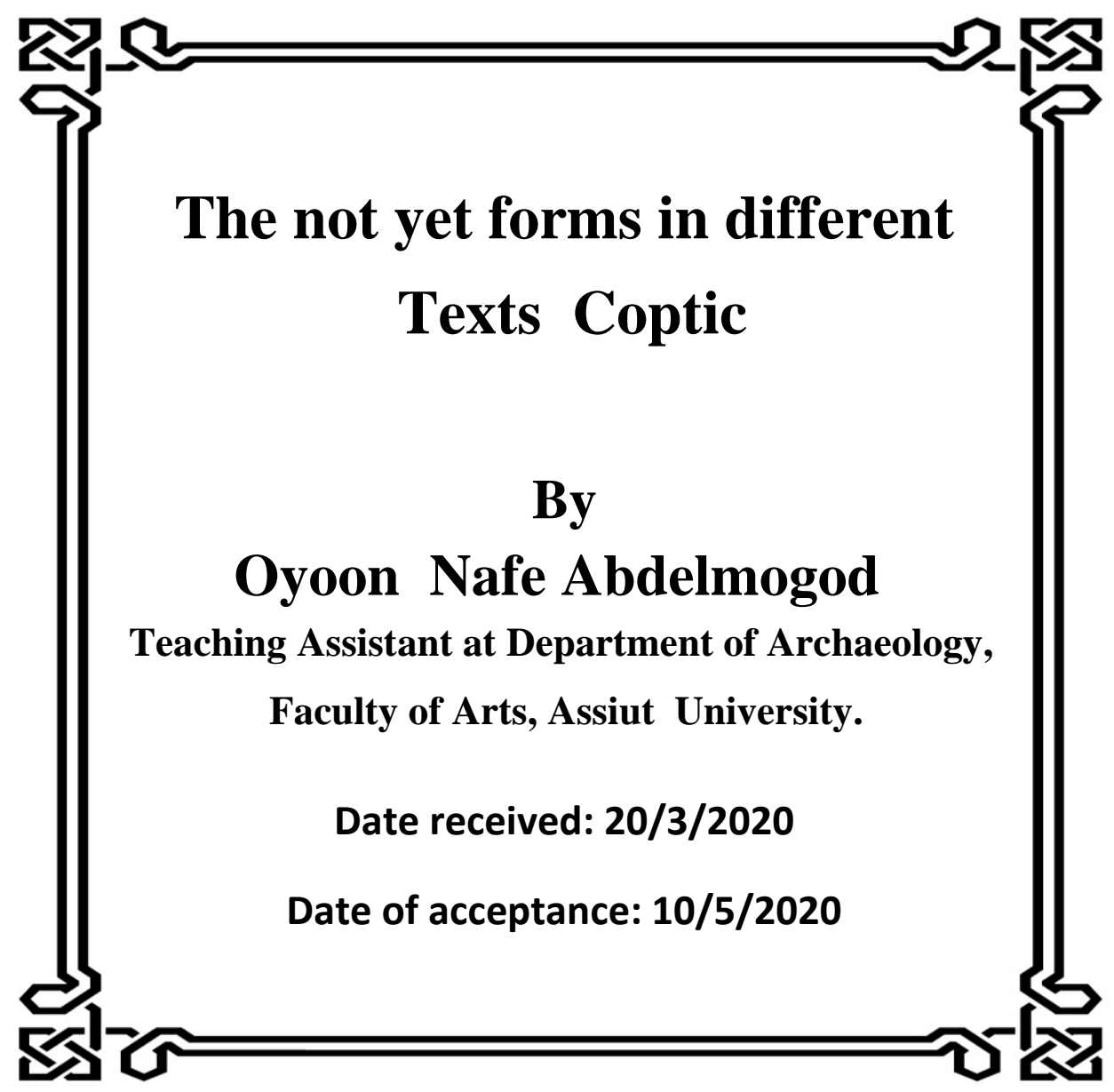





\section{The not yet forms in different Texts Coptic}

\section{Abstract}

This form in Coptic is used to describe an action that is not yet happened, the auxiliary verb used here is $\dot{\mu n d \tau " ~} \operatorname{ind} \tau e$, form the origin $b w$ $i r=t w$.

This study is one of the importance of this subject for the researcher of ancient Egyptian language, It is used to describe an action that is not yet happened , Tens of scholars called it "Not yet". The Late Egyptian construction bw iri.t.f $s \underline{d m}$ entitled in French (pas encore) and in German (noch nicht) which means in English (Not yet), it is a construction derived from Middle Egyptian form $n$ sdm.t.f "He has not heard". make the researcher reach to the best translations for the texts, and this is very important for any language to identify the Historical events and to understand their true meaning.

\section{صيخ ليس .... بعد في النصوص القبطية المختلفة}

تعتبر هذه الصيغة من أهم الصيغ في اللغة المصرية القديمة، وهي تتفي حدث منوقع حدوثة في المستقبل أي أنها تتفي حدث لفترة زمنية معينة معينة، وهذة الصيغة لم تكن وليدة الخط القبطي بل كانت لها أصول في اللغة المصرية القديمة فكانت معروفة منذ العصر الكلاسيكي للغة المصرية القديمة ، وردت في الكثير من النصوص المختلفة، والجدول التالي يوضح تطور صيغ ليس بعد منذ العصر الكلاسيكي وحتي مرحلة القبطي :

\begin{tabular}{|c|c|c|c|}
\hline العصر الكلاسيكي & النقلة بين الكلاسيكي & العصر المتأخر & القبطي \\
\hline$n s \underline{d}$.t.f.f & $b w s \underline{d m} . t . f$ & $b w$ iri.t, $f s d m$ & $\bar{\mu} \Pi \Delta т \bar{\varphi} c \omega \tau \bar{\mu}$ \\
\hline
\end{tabular}

والجدول السابق يوضح تطور صيغ ليس .... بعد منذ العصر الكلاسيكي، حتي العصر القبطي برجع أصلة المصري القديم إلي bw ir=tw ، وهي تتفي حدث متوقع حدوثة مستقبلاً وقد

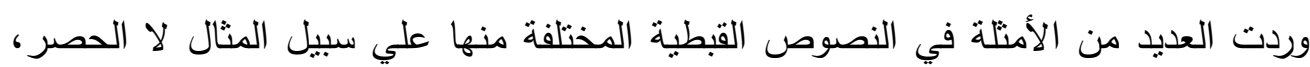
أنجيل يوحنا ولوقا ومتي وكتابات شنودة وغيرها الكثير التي قمنا بعرضها في البحث المعنون " صيخ ليس...بعد في النصوص القبطية " 


\section{Oyoon Nafe Abdelmogod}

Also because of the importance of this subject for the researcher of ancient Egyptian language, It is used to describe an action that is not yet happened, Tens of scholars called it "Not yet". The Late Egyptian construction bw iri.t.f $s \underline{d m}$ entitled in French (pas encore) and in German (noch nicht) which means in English (Not yet), it is a construction derived from Middle Egyptian form $n$ sdm.t.f "He has not heard" (1). make the researcher reach to the best translations for the texts, and this is very important for any language to identify the Historical events and to understand their true meaning.

The transformations of this tense or construction from Middle Egyptian till Late Egyptian and Coptic were as follows: ${ }^{(2)}$

\begin{tabular}{|c|c|c|c|}
\hline $\begin{array}{c}\text { Middle } \\
\text { Egyptian }\end{array}$ & $\begin{array}{c}\text { Transitional } \\
\text { Egyptian; } \\
\text { till Ramsses } 3^{\text {rd }} \text {. }\end{array}$ & $\begin{array}{c}\text { Late } \\
\text { Egyptian }\end{array}$ & Coptic \\
\hline$n$ s $\underline{d m} . t . f$ & $b w s \underline{d m} . t . f$ & $\begin{array}{l}\text { bw iri.t,f } \\
\quad s d m\end{array}$ & $\overline{\boldsymbol{l}} \Pi \Delta \tau \bar{\varphi} \bar{c} \omega \tau \overline{\boldsymbol{l}}$ \\
\hline
\end{tabular}

Now the problem lies with the translation of $n s \underline{d m} . t=f$ with "not yet", which notion appears to be regarded by several scholars as the usual, but nonetheless optional, meaning of the negation in that $s \underline{d m} . t=f$ construction, besides the meaning "not" known from 
the use of the negation in other constructions with finite verb forms, i.e. $n s \underline{d} m=f$ and $\mathrm{n} s \underline{d} m . n=f^{(3)}$ A second problem is the relationship of the form in $n s \underline{d m} . t=f$

This form in Coptic is used to describe an action that is not

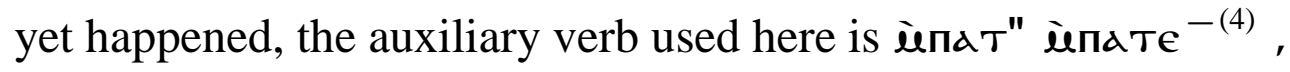
form the origin $b w i r=t w$. Study the following table:

\begin{tabular}{|c|c|c|}
\hline Person & Coptic & Meaning \\
\hline 1 -sc & ünaf mar & I have not yet seen/ before I have seen \\
\hline 2- s m & йпатекпаY & you have not yet seen/ before you have seen \\
\hline 2- $\mathbf{s} \mathbf{f}$ & ёпатена & you have not yet seen/ before you have seen \\
\hline 3- s m & ёпатесіна & He has not yet seen/ before he has seen \\
\hline 3- $\mathbf{s} \mathbf{f}$ & ёпатесіа & She has not yet seen/ before she has seen \\
\hline 1-pl & üпатепाаץ & We have not yet seen/ before we have seen \\
\hline 2-pl & їпатетенাаһ & $\begin{array}{c}\text { you have not yet seen/ before you have } \\
\text { seen }\end{array}$ \\
\hline 3-pl & ёпаторнаһ & $\begin{array}{c}\text { They have not yet seen/ before They have } \\
\text { seen }\end{array}$ \\
\hline $\begin{array}{c}\text { Before } \\
\text { noun } \\
\text { subject }\end{array}$ & ёпате - паץ & $\begin{array}{l}\text { NN have/has not yet seen/ before NN } \\
\text { have/has seen }\end{array}$ \\
\hline
\end{tabular}




\section{Oyoon Nafe Abdelmogod}

Ex. (1)

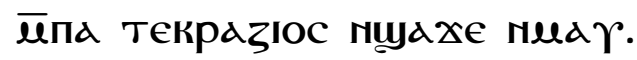

You have not yet become worthy to talk to him. (KHML II $30,12-22)$

Ex. (2)

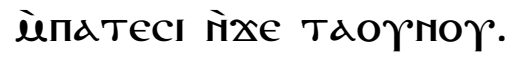

It has not yet come, namely my houer.

Ex. ( 3)

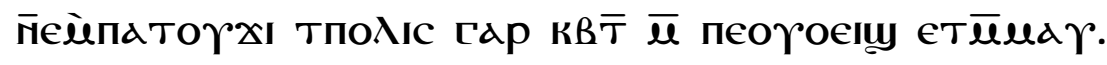

They had not yet taken they the city of kebt at that time. (selection F 75, form the life of Bishop)

Ex. (4)

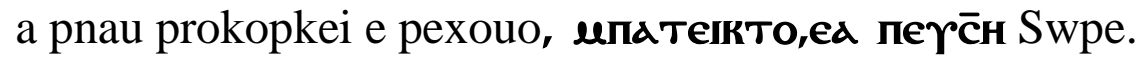

The hour had advanced greatly, I had not returned yet and it was becoming night.(P of pisentius. 137)

In this $\mathrm{E}$ 
Ex. ( 5)

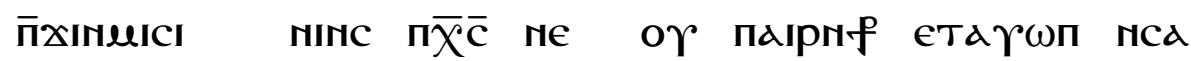
जil

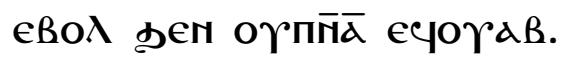

Espoused to Joseph not yet they came together, she was found with child of the Holy Ghost.(Gospel of st. Matthew.1.18)

Ex. ( 6)

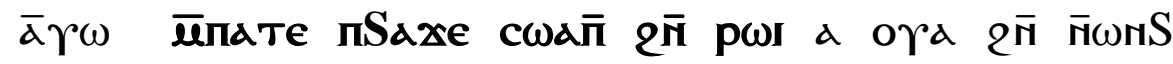
etmmau neJ оunб $\overline{\boldsymbol{n}}$ 2роoү, a

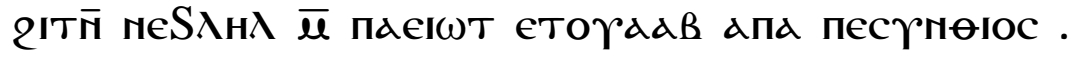

And the words had still not broken yet forth form my mouth, [when] one of those wolves hurled aloud sound, and they all withdrew (themselves) by the prayers of my holy father pisentius . .( The life of Bishop pisentius . 147)

Ex. ( 7)

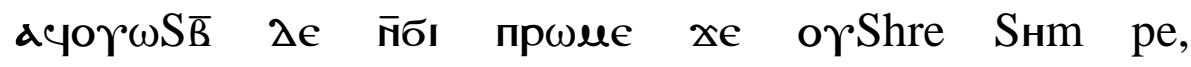

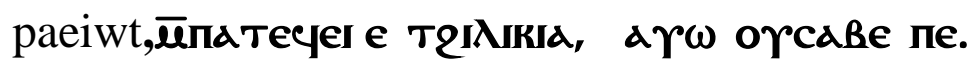

The man answered: He is youth, my father, and he has not yet come to the age, and he is a wise [boy].( The life of Bishop pisentius 159). 


\section{Oyoon Nafe Abdelmogod}

Ex. ( 8)

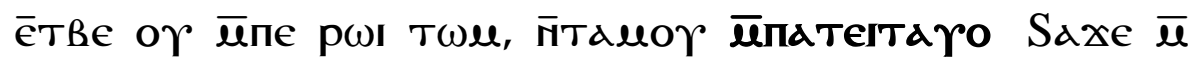
пегоо етеиеа ?

Why did my mouth not [ remain] shut, and [ why did I not] die yet I spoke on that day? ( The life of Bishop pisentius 228).

Ex. (9)

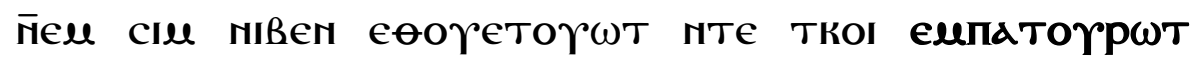

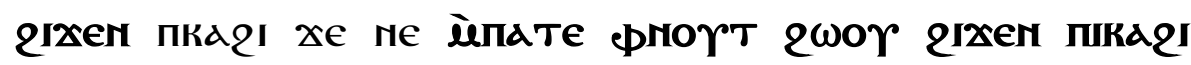

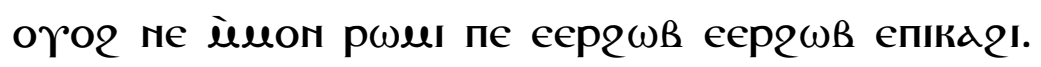

All the trees of the wilderness were not yet on the earth, and all the weeds of the wilderness were not yet grown, because the Lord God had not rained on the earth, nor was a person working on the earth.(see Genesis B.5)

\section{Ex (10)}

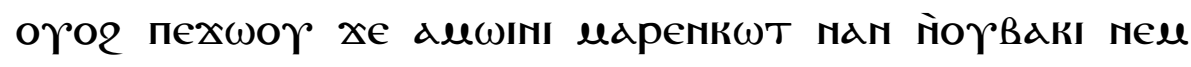

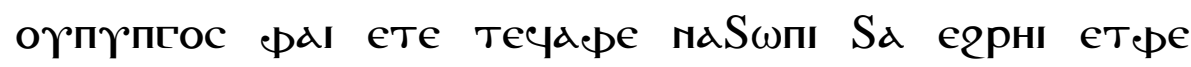

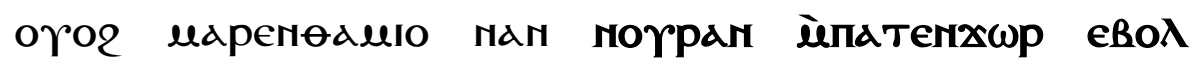
гікеп пұо ӥпкаг тнре.

And they said, Come, let us build a city and a tower whose head is in the sky, and make a name for ourselvesWe are not dissipated yet on the face of all the earth. .(see Genesis 11.4) 


\section{Ex (11)}

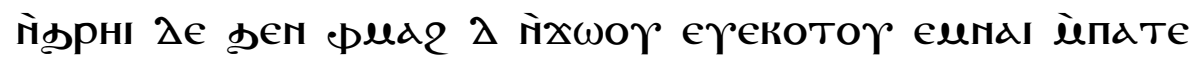

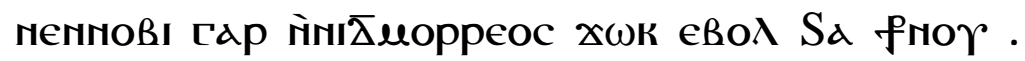

And in the fourth generation, they return here because the Amorites 'guilt is not yet complete.(see Genesis 15.16) ${ }^{(5)}$

\section{Ex (12)}

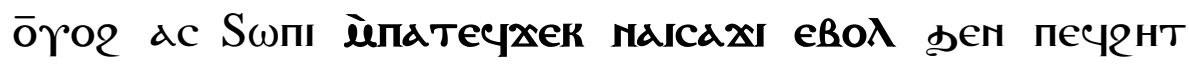

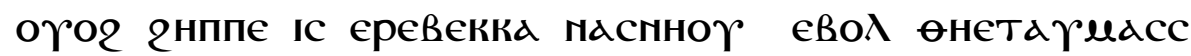

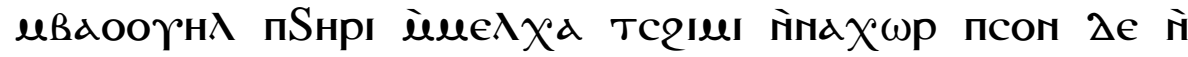

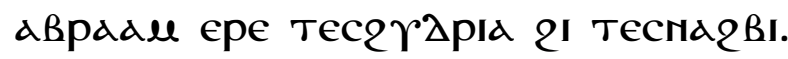

And if he had not yet finished speaking, if Rebekah, who was born to Bettuel, the son of the queen of the woman, Nahor, my brother Ibrahim, went out and dragged her over her shoulder.(see Genesis 24.15)

\section{Ex (13)}

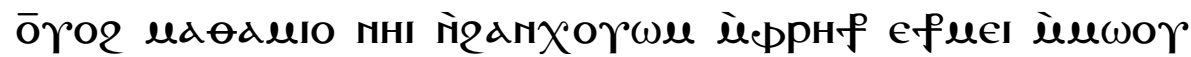

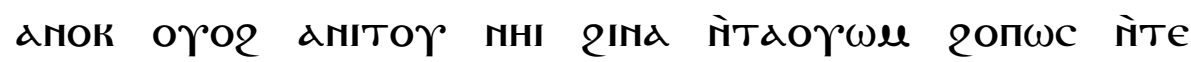

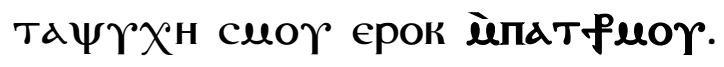

Make food for me as I like and bring it to eat until I bless you myself before I die.(see Genesis 27.4) 


\section{Oyoon Nafe Abdelmogod}

\section{Ex (14)}

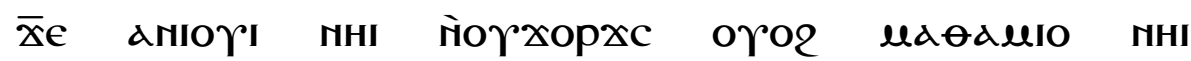

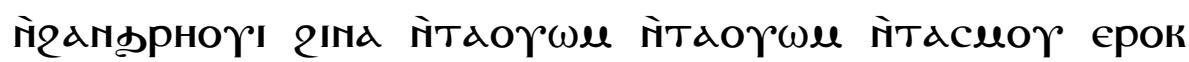

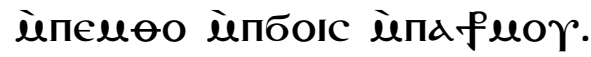

You bring me hunting and make food for me to eat and bless you before the Lord before my death.(see Genesis 27.7)

\section{Ex (15)}

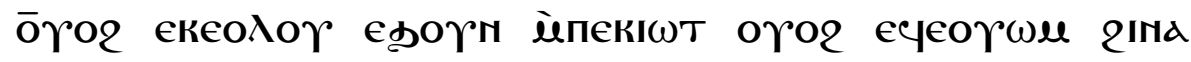

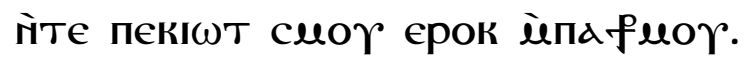

Bring her to your father to eat so that he can bless you before his death.(see Genesis 27.10)

\section{Ex (16)}

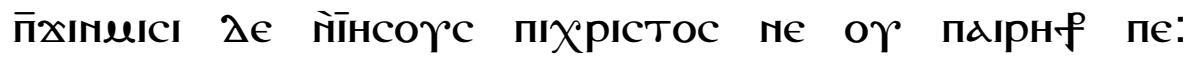

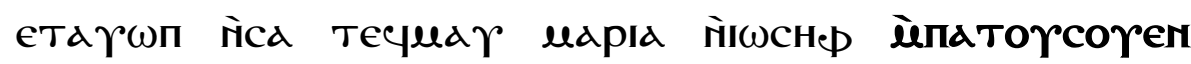

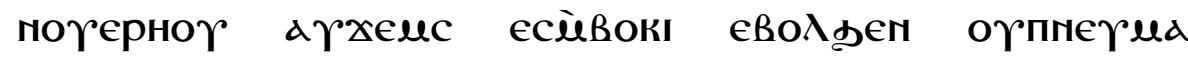
eсорав.

As for the birth of Jesus Christ, it was like this, when Mary, his mother, was engaged to Joseph before they gathered, and she was pregnant with the Holy Spirit..(Gospel of st. Matthew.1.18) 


\section{Ex (17)}

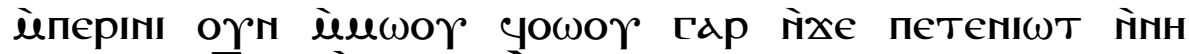

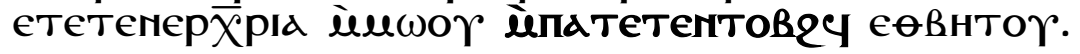

Do not imitate them, because your father knows what you need not yet you ask him..(Gospel of st. Matthew.6.8)

Ex (18)

\section{in middle Egyptian}

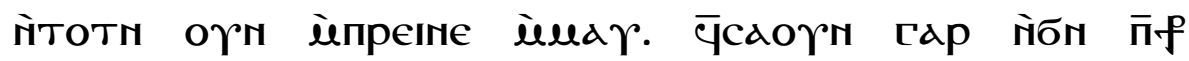

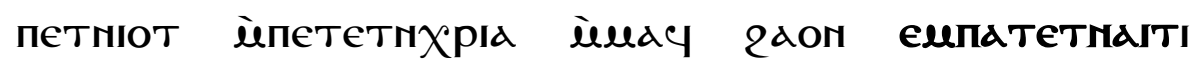
iude.

Be not yet therefore like unto them: for your father knoweth what thing you have need of, before you ask him.

\section{Ex (19)}

\section{In sahidic}

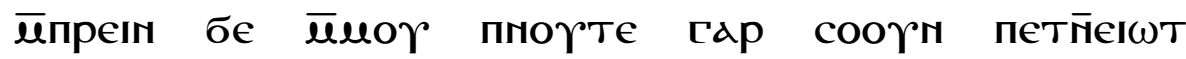

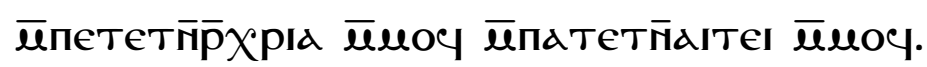

Ex (20)

\section{Sahidic}

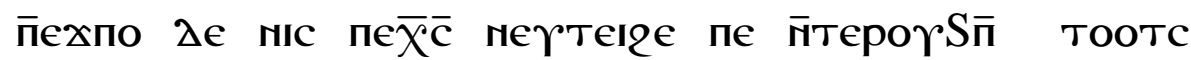

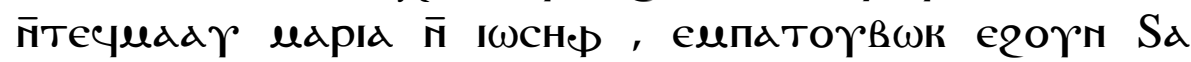
меүернү.

As for the birth of Jesus Christ, it was like this when Mary, his mother, was engaged to Joseph before they go.(G.M.1.18). 


\section{Oyoon Nafe Abdelmogod}

\section{References:}

(1) Neveu, (1998: 91).

${ }^{(2)}$ Neveu (1998: 91).

${ }^{(3)}$ For "not" or "not (yet)" see, among others, Gardiner, EG, 316 (§401): "[sDmt.f] after $\mathrm{n}$ 'not', chiefly with the meaning 'he has (had) not yet heard"'; 317 (\$402): "lit. 'he has (had) not (yet) ...'"; however, Gardiner has stated that the 'not yet/before' notion is only very rarely absent (see Studies sDm.t=f $I$ (Dr sDm.t=f), §1 [p. 4]). Lefebvre, GEC, 212 (§421): "la construction négative n cDmt.f signifie, dans une proposition principale: 'il n'a (n'avait) pas (encore) entendu'". Callender, Middle Egyptian, 103 (4.10.1.1): "the main clause is apparently iw $n \mathrm{sDmt}$. $f$ 'he has not yet heard'; the conjoined form in n sDm.t=f 'when/and he had not heard'". Borghouts, Egyptisch I, 104 (§48.a.1): n sDm.t=f "'hij heeft nog niet gehoord' (eigl. 'hij zal niet hebben gehoord')" ["'he has not yet heard' (strictly speaking 'he will not have heard')"]. Graefe, Mitteläg. Grammatik, 101: "'ohne dass ...' bzw. 'bevor noch'". Grandet - Mathieu, Cours d'égyptien II, 143 (42.4): "on les rend de préférence par 'avant qu'il n'ait mangé' ou 'n'ayant pas encore mangé'...(lit., 'tandis qu'il n'a pas mangé')".

(4) Layton (2000: 260).

${ }^{(5)}$ see Genesis 18.11 


\section{Bibliography}

- Brovarski $(1989)=$ E. Brovarski, The inscribed material of the first Intermediate

- Period from Naga-ed-Der, Diss., Chicago Uni., Chicago.

- Crum (1939) = W. E. Crum, A Coptic Dictionary, Oxford.

- Edgerton $(1931)=$ W. Edgerton, On the Late Egyptian negative bw, AJSL 48/1, 27-44.

- El-Hamrawi (2007) = M. El-Hamrawi, The negative particles $\mathrm{n}, \mathrm{m}, \mathrm{bw}$ and mpe as

- features of dialects in ancient Egyptian language, BSAC 46, 31-60.

- Erman $(1894)=$ A. Erman, Ein neuer der alten Flexion im Koptishen, ZÄS 32, 128- 130.

- Erman (1933) = A. Erman, Neuägyptische Grammatik, Leipzig.

- Frandsen (1974) = P. Frandsen, An Outline of the Late Egyptian Verbal System,

- Copenhagen.

- Gardiner (1957) = A.H. Gardiner, Egyptian Grammar, Oxford. 
- Gunn (1924) = B. Gunn, Studies in Egyptian Syntax, Paris.

- Junge (2005) = F. Junge, Late Egyptian Grammar, 2nd Ed, Oxford

- Kruchten (1999) = J.-M. Kruchten, From Middle Egyptian to Late Egyptian, LingAeg 6,

- $1-96$.

- Neveu (1998) = F. Neveu, La Langue des Ramsès, Grammaire du Néo-égyptian, Paris.

- Polotsky (1969) = H. J. Polotsky, Zur altägyptischen Grammatik, Orientalia 38, 15-31.

- Satzinger (1976) = H. Satzinger, Neuägyptische Studien, Wien

- Selden (2013) = D. Selden, Hieroglyphic Egyptian, London.

- Westendorf (1965) = W. Westendorf, Koptisches Handwörterbuch, Heidelberg.

- Winand $(1992)=$ J. Winand, Etudes de néo-égyptien, 1 le morphologie verbale,

- AEgyptiaca leodiensia; 2, Liège 